\title{
The Impact of Corporate Governance Characteristics on the of Financial Distress
}

\author{
Reza Jarrahi Moghaddam
}

Department of Accounting, Sabzevar Branch, Islamic Azad University, Sabzevar Branch, Iran

\begin{abstract}
Mahdi Filsaraei
Department of Accounting, Sabzevar Branch, Islamic Azad University, Sabzevar Branch, Iran E-mail: filsaraei@yahoo.com
\end{abstract}

Received: Oct. 25, 2016

doi:10.5296/ifb.v3i2.10370
Accepted: Nov. 9, 2016 Published: Dec. 4, 2016

URL: http://dx.doi.org/10.5296/ifb.v3i2.10370

\begin{abstract}
Given the importance of corporate governance for increasing the monitoring of company operations, i.e., reducing information asymmetry and increasing control over operations, in this study, we investigate some indicators of corporate governance and financial distress as one of the most important criteria in the decisions of the users of financial statements. Corporate governance Indicators that have been mentioned in this study, including the independence of the board of directors (the ratio of non-executive members), institutional investors and duality of CEO and Chairman of the Board of Directors. This study is applied research and the required information is gathered from financial statements of listed companies on the TSE. Using a sample of 82 company stock during the period 2010-2014 and multivariate regression analysis, the results of the analysis of information gathered indicates that institutional ownership reduces the financial distress. However, there was no significant relationship between board independence (proportion of outside board members) and the duality of CEO and Chairman of the Board with the financial distress. The results also indicate that financial leverage and a qualified audit opinion increases financial distress and firm size and management performance reduces it.
\end{abstract}

Keywords: Corporate governance, Financial distress, Independence of the board, Ownership of institutional shareholders 


\section{Introduction}

Financial distress, which is known as financial crisis, financial turbulence and financial confusion in financial literature, is terms used in conditions in which the corporates are disable to fulfill their commitments and pay their debts. Corporates financial distress might be temporal. But if the corporate financial condition is not improved, it may cause to bankruptcy in company. The financial distress does not always lead to bankruptcy, but without any exception, all companies face financial distress before bankruptcy (Wu, 2010). Financial distress is costly for both creditors and shareholders. Because when the company is experiencing financial distress, there is a potential risk to wipe out Shareholders' capital. Although at the time of bankruptcy and liquidation of companies, after paying debts to creditors, shareholders can receive their share from the company, in many cases, the remaining capital rarely meets the debt of creditors. Thus, like any other source of risk, it is expected that companies stock which experiencing financial distress, get more return than healthy companies stocks.

Forming a limited company and opening its ownership to the public, will have a significant effect on corporate governance. Market system was organized in such a way that the corporates owners delegate corporate leadership to companies' managers. Separation of "ownership" from "management" leads to the generalization of "Agency" issue. In this problem, it is assumed the conflict between maximizing the profits of Employers and Agents. Solving the agency problem provides the confidence for the shareholders to the extent in which managers try to maximize their profits. There should be enough monitoring to ensure the accountability of enterprises against people and stakeholders. Supervision in this area requires the existence of appropriate mechanisms. In agency relations, the purpose of owners is to maximize wealth and in order to achieve this goal, the agent action is monitored and her/his performance is evaluated. Therefore, it seems necessary to examine the relationship between the ownership structure and the performance of company to have a better and more accurate evaluation on the managers' performance.

On the other hand, one of the humans' concerns is Uncertainty. Investors usually tend to predict the future and like to be aware about it. Accounting knowledge aims to provide useful information for economic decision-making. Over the last 40 years, bankruptcy prediction has been considered as one of the major research fields in financial literature. Many researchers have tried to discover the best bankruptcy prediction models according to the economic and financial environments based on available information and statistical techniques.

The ability to predict financial and commercial bankruptcy, both from the perspective of private investors and also from a social perspective, is important, since it is a clear sign of a misallocation of resources. The early warning about the possibility of bankruptcy enables managers and investors to take preventive action and recognize favorable investment opportunities from unfavorable opportunities. The side and negative effects of bankruptcy does not only influence the bankrupt company and merchant, but also depending on the scope of merchant or commercial enterprise Third parties, creditors and also parties in the transaction with the merchant are affected by it. In cases of vast company activity, bankruptcy 
leads to unemployment of workers and would have unpleasant consequences for the economy (Chen, Kim, Nofsinger, \& Rui, 2007, p. 427).

\section{The Importance and Necessity of Research}

According to the recent events, there is no doubt in the importance of corporate governance for company successes and also improvement in social welfare. The collapse of major companies such as Enron, WorldCom, Cisco, Global Crossing, Sunbeam, Tyco, and Xerox and etc., were caused by weak corporate governance that led to the losses of many investors and stakeholders, indicate the importance of emphasize on improvement and modification of corporate governance in international scale.

Following the collapse of Enron and similar cases, countries around the world quickly showed inhibitory response to similar incidents. As a quick response to these collapses, in the United States, Sarbanes-Oxley Act was approved in July 2002 which was put into force from 2004. In January 2003, Hicks and Smith report was released in Great Britain in response to failures of corporate governance. Therefore, in this research, we will evaluate one of the main and important impacts of corporate governance. The results of this study can indicate one of the other important aspects of corporate governance and the importance of implementing its mechanisms.

\section{Desired Methods for Analyzing Data and Testing Hypotheses}

Data analysis is done in two parts: descriptive and inferential statistics. In central index of the mean and median and standard deviation dispersion index will be used in the descriptive statistics part. And in inferential statistics part, multi-variable regression will be used using combined data. The main motivation in combination of cross-sectional and time-series data is to provide inference and prediction of characters. There are two methods for analyzing the combined data. In first method, different companies' data must be considered over different homogeneous seasons; in this case, the data are combined together or used as a data panel. F-Limmer test is used to determine the methods of using the combined data. If test results show that the effect of cross-sectional and time coefficients are not significant, all data can be combined with each other and parameters estimation can be done using a classic regression. Otherwise, the data should be considered as panel. Hausman test is used to determine the type of combined data models (fixed effects model or random effects model). In the way that, if there is no correlation between the error component and independent variables, random effects model is appropriate, otherwise, fixed effects model is appropriate. To determine the regression model significance and the parameters obtained from regression model estimation, $\mathrm{F}$ and $t$ statistics are respectively used.

\section{Research Backgrounds}

Manzaneque et al. (2016) in a study explore some mechanisms of corporate governance (ownership and board characteristics) in Spanish listed companies and their impact on the likelihood of financial distress. An empirical study was conducted between 2007 and 2012 using a matched-pairs research design with 308 observations, with half of them classified as distressed and non-distressed. The results confirm that in difficult situations prior to 
bankruptcy, the impact of board ownership and proportion of independent directors on business failure likelihood are similar to those exerted in more extreme situations. These results go one step further, to offer a negative relationship between board size and the likelihood of financial distress. This result is interpreted as a form of creating diversity and to improve the access to the information and resources, especially in contexts where the ownership is highly concentrated and large shareholders have a great power to influence the board structure.

Rajput \& Joshi (2015) investigated the relationship between ownership structure, corporate governance and company performance. In this research, relationship between ownership structure, corporate governance and company performance, ROA, ROE were evaluated using panel regression on listed companies (Apart from banks and financial institutions). Data analysis indicated that, there is a positive relationship between family ownership and ROE ratio, but, Government Ownership and minority shareholders negatively influenced ROE.

Miglani et al. (2015) in a study entitled voluntary structure of corporate governance and the financial distress: evidences from Australia, evaluated the role of voluntary acceptance of corporate governance mechanisms in relieving the company's financial distress status. The results of their study indicated that, accepting the determined mechanisms from corporate governance can be useful for companies.

Vinh (2015) in a study aimed to use the current ratios to predict the financial distress: experimental evaluation of Vietnam market used logistic regression after separating the companies into healthy and troubled companies. The results of the study indicated that, the financial ratios can be used as the first signs of companies' financial distress.

Zhang, Z., Xie, L., \& Lu, X. (2015) carried out a study entitled the Determinants of financial distress in major financial institutions: Evidence from US banks. For this purpose, they applied the Distance-to-Default and Z-Score criteria. The results of this study indicated the importance of none-financial criteria and also capital adequacy ratio for predicting the financial distress.

Lorenzo \& Verdugo (2013) in an essay titled financial distress and company performance studied the effect of bank financial distress on the company's performance in several dimensions. They concluded that due to the financial stress which is created in bank section, the companies have to reduce $6 \%$ of their financial leverage. Also the companies in assess section face a $4 \%$ reduction in which it results the performance level reduction.

Len et al. (2012) in a paper titled "The role of corporate governance on corporate distress during the financial crisis", evaluated the impact of management and ownership structures on Profitability of private banks in America. They concluded that, the corporate governance plays an important role in probability and also prevents the bank bankruptcies.

Kalatzis et al. (2010) has directly evaluated the impact of company governance on financial constraints. They used data from 532 Brazilian public limited companies from 1997 to 2002 and they concluded that ownership focus and higher control increases the financial constraints. 
Funchal et al. (2009) evaluate the corporate governance and bankruptcy according to the amount of debts. The obtained results indicate that the companies with better corporate governance enjoy less debt expense and more credit. And also the results showed that Better surveillance and implementation of tougher laws in relation to bankruptcy has positive impact on the debt.

Chang (2009) by examining the relation between the corporate governance characteristics in companies with financial distress in Taiwan concluded that Companies with Independent board (companies with high percentage Non-executive board members) are less affected by the crisis and financial distress than companies with low percentage of board of directors. The results also indicate that, there is a positive relationship between the size of board of directors and financial distress.

Flitch \& Selzek (2008) evaluated the ability of corporate governance mechanisms in preventing companies' financial distress. They used Z-Altman model and interest coverage ratio to determine the financial distress level. The results indicate that, independent board of directors with high percentage Non-executive board members and also providing a large part of company's shares to General Manager has the most impact on preventing the financial distress.

Fernandese (2008) evaluated the role of Independency of board members in his paper. He studied the relationship between The Company's performance, the Board of Directors and payments to top executive using the data from 511 companies listed in Portugal Stock Exchange from 2002 to 2004 . He concluded that, the non-executive members of board of directors have no Strong supervisory role. Also the companies with zero Non-executive members have a better setting and balance among the shareholders and managers interests and there is less representation problem in these kinds of companies.

\section{Research Hypotheses}

1) There is a significant relationship between the independency of the board of directors and financial distress.

2) There is a significant relationship between the percentage of Ownership of institutional investors and Company Financial distress.

3) There is a significant relationship between the duality of the Board Chairman and CEO duties and Company Financial distress.

\section{The Main Model of the Research and Hypotheses Test Method}

The regression model is used in this research, in order to reach the research objectives and test the hypotheses. In this regard, the following model was used:

$$
\begin{aligned}
& \text { DISTRESS }_{\text {it }}=\beta_{0}+\beta_{1} \text { OUTSIDERS }_{\text {it }}+\beta_{2} \text { INSOWN }_{i t}+\beta_{3} \\
& \text { DUALITY it }+\beta_{4} \text { AUDITOPNit }_{\text {it }}+\beta_{5} \text { LEVERAGE }_{\text {it }}+\beta_{6} \text { SIZE }_{\text {it }}+ \\
& \beta_{7} \text { BIGAUTFIRM }_{\mathrm{it}}+\beta_{8} \text { MGTEFF }_{\text {it }}+\varepsilon_{\mathrm{it}}
\end{aligned}
$$

The variables of the model are as follow: 


\section{Macrothink}

DISTRESSit: financial distress

OUTSIDERSit: independency of board of directors

INSOWNit: institutional ownership

DUALITYit: duality of board chairman and CEO duties

AUDITOPNit: auditor opinion

LEVERAGEit: financial leverage

SIZEit: company size

BIGAUTFIRMit: size of auditor

MGTEFFit: efficiency of Management 


\section{Evaluating the Research}

\subsection{Evaluating the Correlation Coefficient of Research Variables}

Table 1. Correlation coefficient of research variables

\begin{tabular}{|c|c|c|c|c|c|c|c|c|c|c|}
\hline \multicolumn{2}{|c|}{ Variable } & $\begin{array}{l}\text { OUDI } \\
\text { TOP }\end{array}$ & BIGA & Quality & $\begin{array}{c}\text { INSOW } \\
\text { IN }\end{array}$ & MDA & $\begin{array}{c}\text { LEVERAG } \\
\text { E }\end{array}$ & MGTEFF & $\begin{array}{c}\text { OUTSID } \\
\text { ER }\end{array}$ & SIZE \\
\hline \multirow{2}{*}{ OUDITOPN } & $\begin{array}{c}\text { Coeffici } \\
\text { ent }\end{array}$ & 1 & & & & & & & & \\
\hline & $\begin{array}{c}\text { probabil } \\
\text { ity }\end{array}$ & -..- & & & & & & & & \\
\hline \multirow{2}{*}{ BIGA } & $\begin{array}{c}\text { Coeffici } \\
\text { ent }\end{array}$ & -0.22 & 1 & & & & & & & \\
\hline & $\begin{array}{l}\text { probabil } \\
\text { ity }\end{array}$ & 0.00 & $\cdots$ & & & & & & & \\
\hline \multirow{2}{*}{ Quality } & $\begin{array}{c}\text { Coeffici } \\
\text { ent }\end{array}$ & -0.08 & 0.15 & 1 & & & & & & \\
\hline & $\begin{array}{c}\text { probabil } \\
\text { ity }\end{array}$ & 0.10 & 0.00 & -- & & & & & & \\
\hline \multirow{2}{*}{ INSOWN } & $\begin{array}{c}\text { Coeffici } \\
\text { ent }\end{array}$ & 0.00 & 0.10 & 0.05 & 1 & & & & & \\
\hline & $\begin{array}{l}\text { probabil } \\
\text { ity }\end{array}$ & 0.96 & 0.03 & 0.28 & $\cdots$ & & & & & \\
\hline \multirow{2}{*}{ LEVERAGE } & $\begin{array}{c}\text { Coeffici } \\
\text { ent }\end{array}$ & 0.17 & -0.01 & -0.02 & -0.10 & 1 & & & & \\
\hline & $\begin{array}{l}\text { probabil } \\
\text { ity }\end{array}$ & 0.00 & 0.83 & 0.63 & 0.03 & -... & & & & \\
\hline \multirow{2}{*}{ MDA } & $\begin{array}{c}\text { Coeffici } \\
\text { ent }\end{array}$ & -0.17 & 0.13 & 0.05 & 0.15 & -0.09 & 1 & & & \\
\hline & $\begin{array}{l}\text { probabil } \\
\text { ity }\end{array}$ & 0.00 & 0.01 & 0.29 & 0.00 & 0.06 & $\cdots$ & & & \\
\hline \multirow{2}{*}{ MGTEFF } & $\begin{array}{c}\text { Coeffici } \\
\text { ent }\end{array}$ & -0.22 & 0.13 & 0.05 & -0.07 & 0.12 & 0.19 & 1 & & \\
\hline & $\begin{array}{l}\text { probabil } \\
\text { ity }\end{array}$ & 0.00 & 0.00 & 0.28 & 0.15 & 0.01 & 0.00 & $\cdots$ & & \\
\hline \multirow{2}{*}{ OUTSIDERS } & $\begin{array}{c}\text { Coeffici } \\
\text { ent }\end{array}$ & 0.08 & -0.27 & -0.34 & -0.17 & -0.10 & -0.10 & -0.11 & 1 & \\
\hline & $\begin{array}{c}\text { probabil } \\
\text { ity }\end{array}$ & 0.10 & 0.00 & 0.00 & 0.00 & 0.02 & 0.02 & 0.01 & $\cdots$ & \\
\hline \multirow{2}{*}{ SIZE } & $\begin{array}{c}\text { Coeffici } \\
\text { ent }\end{array}$ & 0.01 & 0.12 & -0.07 & 0.08 & 0.09 & 0.19 & -0.21 & 0.03 & 1 \\
\hline & $\begin{array}{l}\text { probabil } \\
\text { ity }\end{array}$ & 0.83 & 0.01 & 0.12 & 0.09 & 0.05 & 0.00 & 0.00 & 0.50 & -.- \\
\hline
\end{tabular}


Results obtained from the correlation coefficient table 1 indicate that, there is a negative relationship between the percentage of the institutional shareholders and financial leverage. The correlation coefficient results of these two variables are compatible with the Theoretical debates and investigation.

\section{Evaluating the Assumptions of Linear Regression Model}

Constant of error sentence variance (residual)

Table 2. Results from testing the error sentence variance constant

\begin{tabular}{|l|l|l|l|l|}
\hline Research models & Used test & F-static & probability & results \\
\hline DISTRESSit & & & & \\
$+\beta 0$ & & & & \\
$+\beta 2$ INSOWNit & & & \\
$+\beta 3$ DUALITYit & & & \\
$+\beta 4$ AUDITOPNit & White & 6.900 & 0.0001 & Dissimilarity of errors variance \\
$+\beta 5$ LEVERAGEit & & & \\
$+\beta 6$ SIZEit & & & \\
$+\beta 7$ BIGAUTFIRMit & & & & \\
$+\beta 8$ MGTEFFit & & & & \\
+ cit & & & & \\
\hline
\end{tabular}

In this study, the assumption of residual variance similarity is evaluated through the white test. The results in table 2 shows that the null hypothesis (similarity of variance) is not confirmed in research model. Therefore, generalized least squares regression GLS is used in order to solve the dissimilarity of variance. 
8.1 The Absence of Autocorrelation of Error Statement (Residuals)

Table 3. Results from testing the absence of autocorrelation of error statement

\begin{tabular}{|l|l|l|l|l|}
\hline Research models & Used test & F-static & probability & results \\
\hline DISTRESSit & & & & \\
$+\beta 0$ & & & & \\
$+\beta 2$ INSOWNIt & & & \\
$+\beta 3$ DUALITYit & Breusch-Godfrey & 20.0410 & 0.0001 & Existence of a second-order \\
$+\beta 4$ AUDITOPNit & & & & autocorrelation \\
$+\beta 5$ LEVERAGEit & & & \\
$+\beta 6$ SIZEit & & & \\
$+\beta 7$ BIGAUTFIRMit & & & & \\
$+\beta 8$ MGTEFFit + cit & & & & \\
\hline
\end{tabular}

The results from the test indicate that, given the fact that the F-static probability is less than 5\% in research model at $95 \%$ confidence level, and then the null hypothesis is not confirmed. Therefore, generalized least squares method is used, in order to solve the serial autocorrelation.

\subsection{Absence of Linearity between Explanatory Statements}

Table 4. The results of the test

\begin{tabular}{|l|l|l|}
\hline Variable & Coefficient variance & Variance inflation factor \\
\hline OUTSIDERS & 0.001 & 1.255566 \\
\hline INSOWN & 0.000 & 1.06012 \\
\hline DUALITY & 0.000 & 1.149487 \\
\hline AUDITOPN & 0.000 & 1.1393630 \\
\hline LEVERAGE & 0.000 & 1.106043 \\
\hline SIZE & 0.000 & 1.101068 \\
\hline BIGE & 0.000 & 1656111 \\
\hline MGTEFF & 0.000 & 1.157656 \\
\hline
\end{tabular}


According to the results of the table 4, the results from this test show that the variance inflation of independent and control variables in the research model have their limits and there is no problem in this regard.

\subsection{Evaluating the Stationary of Research Variables}

The hypotheses related to the Stationary of research variables are as follow:

H0: The variable is Non-stationary

H1: The variable is Stationary

Table 5. The results from testing the Stability of research variables

\begin{tabular}{|l|l|l|l|l|}
\hline & & statistic & probability & \\
\hline Auditor opinion & AUDITOPN & -8.926 & 0.000 & Stationary \\
\hline Auditor size & BIGA & -5.595 & 0.000 & Stationary \\
\hline Duality of CEO & DUALITY & -40.544 & 0.000 & Stationary \\
\hline $\begin{array}{l}\text { Institutional } \\
\text { shareholders }\end{array}$ & INSOWN & -2.025 & 0.021 & Stationary \\
\hline Financial leverage & LEVERAGE & -76.210 & 0.000 & Stationary \\
\hline Financial distress & DISTRESS & -53.809 & 0.000 & Stationary \\
\hline $\begin{array}{l}\text { Management } \\
\text { efficiency }\end{array}$ & MGTEFF & -27.504 & 0.000 & Stationary \\
\hline $\begin{array}{l}\text { Independency } \\
\text { boards of directors }\end{array}$ & OUTSIDERS & -17.053 & 0.000 & Stationary \\
\hline $\begin{array}{l}\text { Company size } \\
\text { SIZE }\end{array}$ & -29.809 & 0.000 & \\
\hline
\end{tabular}

According to the test of Levin, Lin, \& Chu, as the value of all variables are less than $5 \%$, all independent, dependent and control variables are Non-stationary at the research period. Stationary means that, Average and variance of the research variables has been stable over time and Covariance was also constant in different years. 
8.4 F Limer and Hausman Test

Table 6. The results obtained from F Limer and Hausman test

\begin{tabular}{|c|c|c|c|c|c|}
\hline & Test type & $\begin{array}{l}\text { Statistic } \\
\text { value }\end{array}$ & $\begin{array}{l}\text { freedom } \\
\text { degree }\end{array}$ & probability & result \\
\hline \multirow[b]{2}{*}{$\begin{array}{l}\text { DISTRESSit } \\
=\beta 0 \\
+\beta 1 \text { OUTSIDERSit } \\
+\beta 2 \text { INSOWNit } \\
+\beta 3 \text { DUALITYit } \\
+\beta 4 \text { AUDITOPNit } \\
+\beta 5 \text { LEVERAGEit } \\
+\beta 6 \text { SIZEit } \\
+\beta 7 \text { BIGAUTFIRMit } \\
+\beta 8 \text { MGTEFFit }+\varepsilon i t\end{array}$} & F-Limer & 2.0566 & -4.397 & 0.0858 & Consolidated method \\
\hline & Hausman & - & - & - & - \\
\hline
\end{tabular}

\section{The Results from Testing the Research Hypotheses}

According to the fact that, Kordestani \& Tatli's model (2014-2015) is localized, and have more similarity with Iran's economic condition and commercial environment, we will provide the results from testing this model and then the results of other models.

\subsection{Kordestani and Tatli’s Localized Model (2014-2015)}

The results from estimating the provided research model in table 7 is used in order to test the hypotheses by this model. The probability value (or the significance level) of $\mathrm{F}$ is equal to 0.0000 , and as this value is less than 0.05 , the null hypothesis is not confirmed at the $95 \%$ confidence level. It means that the model is significant. The static value of Durbin-Watson is equal to 1.5499; this value shows the absence of errors autocorrelation (first order). The results related to the adjusted coefficient of determination shows that, 0.15 of dependent variable changes are explained by independent and control variable. The results of testing the research hypotheses are as follow: 
Table 7. The results from estimating the research model

\begin{tabular}{|c|c|c|c|c|c|}
\hline \multicolumn{6}{|c|}{$\begin{aligned} \text { DISTRESSit } & =-2 / 54-0 / 570 \text { OUTSIDERSit }+0 / 0033 \text { INSOWNit }-0 / 012 \text { DUALITYit } \\
& -0 / 236 \text { AUDITOPNit }-0 / 602 \text { LEVERAGEit }+0 / 220 \text { SIZEit } \\
& +0 / 007 \text { BIGAUTFIRMit }+0 / 466 \text { MGTEFFit }+\varepsilon i t\end{aligned}$} \\
\hline Variable & sign & $\begin{array}{l}\text { The estimated } \\
\text { coefficient }\end{array}$ & $\begin{array}{l}\text { standard } \\
\text { error }\end{array}$ & t-static & probability \\
\hline Constant value(intercept) & $\mathrm{C}$ & -2.54143 & 0.63189 & -4.02196 & 0.00010 \\
\hline $\begin{array}{l}\text { Board of directors } \\
\text { independency }\end{array}$ & OUTSIDERS & -0.57015 & 0.31432 & -1.8139 & 0.07030 \\
\hline Institutional shareholders & INSOWN & 0.00333 & 0.00139 & 2.39859 & 0.01680 \\
\hline CEO duality & DUALITY & -0.01290 & 0.14042 & -0.0918 & 0.92680 \\
\hline Auditor opinion & AUDITOPN & -0.23632 & 0.09281 & -2.5462 & 0.01120 \\
\hline Financial leverage & LEVERAGE & -0.60287 & 0.14932 & -4.0374 & 0.00010 \\
\hline Company size & SIZE & 0.22076 & 0.03826 & 5.77052 & 0.00000 \\
\hline Auditor size & BIGA & 0.00797 & 0.11372 & 0.07005 & 0.94420 \\
\hline Management efficiency & MGTEFF & 0.46602 & 0.09940 & 4.68839 & 0.00000 \\
\hline Determination coefficient & \multicolumn{5}{|l|}{0.162736} \\
\hline $\begin{array}{l}\text { adjusted determination } \\
\text { coefficient }\end{array}$ & \multicolumn{5}{|l|}{0.148545} \\
\hline Durbin-Watson & \multicolumn{5}{|l|}{1.54998} \\
\hline F-statistic & \multicolumn{5}{|l|}{11.46765} \\
\hline Probability (F-statistic) & \multicolumn{5}{|l|}{0.00000} \\
\hline
\end{tabular}

The first hypothesis of the research: there is a significant relationship between board of director independency and company financial distress.

In the general state, the results indicate that the variable coefficient of board of director independency is equal to 0.57 which indicates a negative relationship between board of director independency and financial health. In the other word, there is a positive relationship between board of director independency and company financial distress. So it is not significant, given the significance level (0.07) which is more than 5\%. According to above, the first hypothesis is not confirmed.

The second hypothesis: there is a significant relationship between the institutional shareholders' ownership and company financial distress.

In the general state, the results indicate that the variable coefficient of the institutional 
shareholders' ownership is equal to 0.003 which indicates a positive relationship between institutional shareholders' ownership and financial health. In the other word, the institutional shareholders' ownership can lead to a reduction in financial distress, so it is significant according to the significance level $(0.016)$ which is less than $5 \%$. Therefore the second hypothesis is confirmed.

The third research hypothesis: there is a significant relationship between duality of chief of board of director and CEO duties and company financial distress.

In the general state, the results indicate that the variable coefficient of duality of chief of board of director and CEO duties is equal to -0.012 which indicates a negative relationship between duality of chief of board of director and CEO duties and financial health. In the other word, the duality of chief of board of director and CEO duties can lead to an increase in financial distress, so it is not significant according to the significance level (0.92) which is more than 5\%. Therefore the third hypothesis is not confirmed.

\subsection{Results of Testing the Control Variables}

According to the results of the research and significance level, it can be concluded that, the size of the company (0.022076) and management efficiency (0.46602) leads to an increase in financial health (reduction in financial distress) and also auditor opinion (-0.23632) and financial leverage lead to an decrease in financial health (increase in financial distress). Other control variables are not statistically significant.

\section{Applicable Suggestions}

A. The results of the research indicate an increase in financial health in companies with more institutional shareholders ratio. According to the results of the research it is suggested that, the role of this factor in the investing models must be considered by those active in capital market and also investors in making decisions in the field of buying and selling stock.

B. According to the results of the third hypotheses in negative impact of CEO duality from board of director chief on financial distress, it is suggested that Legislators can contribute to improving the supervisory role of the Board for improving the performance of stock companies and preventing financial distress, by the adopting rules in this regard.

\section{Recommendations for Future Researches}

A. According to the role and place of auditing quality as one of the effective factors of company governance in improving the monitoring on operation and performance of company, and also the results from previous researches and theatrical principles provided in this regard, it is suggested to evaluate the role and impact of effective indicators on auditing quality including the auditor tenure, specialty in auditor industry and etc on financial distress.

B. According to the different models to predict the financial crisis, it is suggested to evaluate the impact of corporate governance indicators on other measurement indicators of financial crisis. 
C. According to fact that many companies are bankrupt after the crisis, it is suggested to evaluate the impact of corporate governance indicators on companies' bankruptcy.

\section{References}

Abu-Tapanjeh, A. M. (2009). Corporate governance from the Islamic perspective: A comparative analysis with OECD principles. Critical perspectives on Accounting, 20(5), 556-567. https://doi.org/10.1016/j.cpa.2007.12.004

Altman, E. I. (1993). Financial ratios, discriminant analysis, and the prediction of the corporate bankruptcy. The Journal of Finance, 23, 589-609. https://doi.org/10.1111/j.1540-6261.1968.tb00843.x

Chang, C. (2009). The Corporate Governance Characteristics of Financially Distressed Firms: Evidence from Taiwan. The Journal of American Academy of Business, 15(1), 125-132.

Chen, G., Kim, K., Nofsinger, J., \& Rui, O. (2007). Trading Performance, Disposition Effect, Over confidence, Representativeness Bias, and Experience of Emerging Market Investors. Journal of Behavioral Decision Making, 20, 425-451. https://doi.org/10.1002/bdm.561

Fich, E. M., \& Slezak, S. L. (2008). Can corporate governance save distressed firms from bankruptcy? An empirical analysis. Rev Quant Finan Acc, 30, 225-251. https://doi.org/10.1007/s11156-007-0048-5

Elloumi, F., \& Gueyle, P. J. (2001). Financial distress and corporate governance: An empirical analysis. Corporate Governance, 1(1), 15-23. https://doi.org/10.1108/14720700110389548

Fernandese, N. (2008). EC: Board compensation and firm performance: The role of "independent" board members. Journal of multinational financial management, 18(1), 30-44. https://doi.org/10.1016/j.mulfin.2007.02.003

Funchal, B., CaioGaldi, F., \& Broedel, L. A. (2010). Interactions between Corporate Governance, Bankruptcy Law and Firms' Debt Financing: the Brazilian Case. [Online] Available: http://www.anpad.org.br/bar

Gillan, S. L., \& Starks, L. T. (1998). A survey of shareholder activism: Motivation and empirical evidence. Contemporary Finance Digest, 2(3), 10-34. https://doi.org/10.2139/ssrn.663523

Gordon, M. J. (1971). Towards a theory of financial distress. The Journal of Finance, 26, 347-356. https://doi.org/10.1111/j.1540-6261.1971.tb00902.x

Jensen, M. C. (1986). Agency Costs of Free Cash Flow, Corporate Finance and Takeovers. American Economics Review, 76, 323-339.

Kalatzis, A. G., Pellicani, A. D., \& Moccellin, J. V. (2010). The impact of corporate governance on financial constraint: evidence from Brazilian firms. International Conference on Applied Economics-ICOAE, 389-395. 
Kouki, M., \& Elkhaldi, A. (2011). Toward a Predicting Model of Firm Bankruptcy: Evidence from the Tunisian Context. Middle Eastern Finance and Economics, 14, $26-43$.

Lorenzo, E., \& Verdugo, B. (2013). Bank financial distress and firm performance. The university of chicago, 3595883 .

Manzaneque, M., Priego, A. M., \& Merino, E. (2016). Corporate governance effect on financial distress likelihood: Evidence from Spain. Revista De Contabilidad, 23(1), 111-121. https://doi.org/10.1016/j.rcsar.2015.04.001

Miglani, S., Ahmed, K., \& Henry, D. (2015). Voluntary corporate governance structure and financial distress: Evidence from Australia. Journal of Contemporary Accounting \& Economics, 11, 18-30. https://doi.org/10.1016/j.jcae.2014.12.005

Ohlson, J. A. (1980). Financial ratios and probabilistic prediction of bankruptcy. The Journal of Accounting Research, 131-1069. https://doi.org/10.2307/2490395

Rajput, N., \& Joshi, B. (2015). Shareholder Types, Corporate Governance and Firm Performance: An Anecdote from Indian Corporate Sector. Asian Journal of Finance \& Accounting, 7(1), 45-63. https://doi.org/10.5296/ajfa.v7i1.6070

Spence, A. M., \& Zeckhauser, R. J. (1971). Insurance, Information and Individual Action. American Economic Review, 380-391.

Vinh, V. (2015). Using Accounting Ratios in Predicting Financial Distress: An Empirical Investigation in the Vietnam Stock Market. Journal of Economic Development, 17(1), 41-49.

Whitaker, R. (1999). The Early Stage of Financial Distress. Journal of Economics and Finance, 23(2), 123-133. https://doi.org/10.1007/BF02745946

Wu, Y. (2010). Does Financial Distress Risk Drive the Momentum Anomaly? Evidence from the U.S. Market. Master's thesis, Aalto University.

Zhang, Z., Xie, L., \& Lu, X. (2015). Determinants of financial distress in large financial institutions: evidence from U.S. bank holding companies. Contemporary Economic Policy.

Zmijewski, M. E. (1984). Methodological Issues Related to the Estimation of Financial Distress Prediction Models. Journal of Accounting Research, 24, 59-82. https://doi.org/10.2307/2490859

\section{Copyright Disclaimer}

Copyright for this article is retained by the author(s), with first publication rights granted to the journal.

This is an open-access article distributed under the terms and conditions of the Creative Commons Attribution license (http://creativecommons.org/licenses/by/3.0/). 